\title{
FIRST RECORD OF GAMMARUS ROESELII GERVAIS, 1835 (AMPHIPODA: GAMMARIDAE) FROM KOSOVO WITH ECOLOGICAL NOTES
}

\author{
Ruzhdi KuçI ${ }^{1}$, Halil Ibrahim $^{2 *}$ \& Agim Gashi ${ }^{2}$ \\ ${ }^{1}$ Faculty of Education, University of Prishtina "Hasan Prishtina", "Agim Ramadani" street p.n., \\ 10000 Prishtina, Republic of Kosovo \\ ${ }^{2}$ Department of Biology, Faculty of Mathematical and Natural Sciences, University of Prishtina \\ "Hasan Prishtina", “Mother Theresa" street p.n., 10000 Prishtina, Republic of Kosovo
}

Kuçi, R., Ibrahimi, H. \& Gashi, A.: First record of Gammarus roeselii Gervais, 1835 (Amphipoda: Gammaridae) from Kosovo with ecological notes. Nat. Croat., Vol. 26, No. 2., 215-223, Zagreb, 2017.

Knowledge of the composition and distribution of Gammaridae fauna in Kosovo is very poor. Amphipod specimens were collected monthly during 2010 at five sites in five different tributaries of the Toplluhë and Mirushë rivers in Kosovo. Three species of the genus Gammarus Fabricius, 1775 were found: Gammarus balcanicus Schäferna, 1922, Gammarus fossarum Koch, 1836 and Gammarus roeselii Gervais, 1835. Gammarus roeselii was found for the first time in the Republic of Kosovo at one site only, in the Banjë thermal spring, as the only Gammaridae species. The water temperature regime of this site $\left(18-25^{\circ} \mathrm{C}\right)$ enables constant reproduction. The population structure of $G$. roeselii was dominated by males during most of the research period, probably due to the fact that they reach maturity earlier than females and are characterized by faster growth.

Keywords: Gammarus roeselii, Kosovo, Amphipoda, first record

Kuçi, R., Ibrahimi, H. \& Gashi, A.: Prvi nalaz vrste Gammarus roeselii Gervais, 1835 (Amphipoda: Gammaridae) s Kosova s detaljima iz ekologije. Nat. Croat., Vol. 26, No. 2., 215-223, Zagreb, 2017.

Poznavanje sastava i rasprostranjenosti faune porodice Gammaridae na Kosovu je vrlo oskudno. Primjerci Amphipoda su prikupljani mjesečno tijekom 2010 na 5 postaja na 5 različitih pritoka rijeka Toplluhë i Mirushë na Kosovu. Nađene su tri vrste roda Gammarus Fabricius, 1775: Gammarus balcanicus Schäferna, 1922, Gammarus fossarum Koch, 1836 i Gammarus roeselii Gervais, 1835. Gammarus roeselii je nađen po prvi puta za Republiku Kosovo na jednom lokalitetu, u termalnom izvoru Banjë, kao jedina vrsta porodice Gammaridae. Temperaturni režim vode na tom lokalitetu $\left(18-25^{\circ} \mathrm{C}\right)$ omogućava stalnu reprodukciju. U populacijskoj strukturi vrste G. roeselii tijekom većine istraživanog razdoblja dominiraju mužjaci, vjerojatno zbog činjenice da postižu zrelost ranije od ženki i karakterizira ih brži rast.

Ključne riječi: Gammarus roeselii, Kosovo, Amphipoda, prvi nalaz

\section{INTRODUCTION}

Amphipods are important organisms in aquatic food webs, contributing importantly to the material cycle, life and diversity in freshwater systems. Another important aspect of their presence, especially in freshwater environments, is their use as indicators of water quality (e.g. Altermatt, 2014) and in ecotoxicology assessment studies (e.g. Davolos et al., 2015). Gammaridae Leach, 1814 is the largest family

* corresponding author: halil.ibrahimi@uni-pr.edu 
of the crustacean order Amphipoda Latreille, 1816. Species of this family live in different habitats in freshwater, brackish and marine ecosystems, mostly on the bottom in shallow areas among stones, roots and vegetation (e.g. VÄINÖLÄ et al., 2008).

The genus Gammarus Fabricius, 1775, with more than 200 species, inhabits marine and freshwater environments; while most are epigean, some of them have been reported from caves and wells (Karaman \& Pinkster, 1977a; Özbek et al., 2013). Species of this genus are distributed in the Holarctic and Palearctic regions. Amphipod fauna of the Balkan Peninsula is moderately known thanks mainly to the taxonomic works by Stanko and Gordan Karaman and a few other authors (e.g. Karaman, 1934, Karaman, 1972, 1973, 1974; Karaman \& Pinkster, 1977a, 1977b; Žganec et al., 2010; Grabowski \& Pešić 2007; Grabowski et al., 2017), but there are areas where there is still lack of knowledge on the taxonomy, biogeography and ecological features of this order. Kosovo is one of the least explored countries in Southeastern Europe with regards to gammarids. Data on the distribution of gammarids at a few sites in Kosovo are provided only by Ibrahimi et al. (2008), Shukriu (1976), Živić \& Marković (2007) and Žıvić et al. (2012).

The goal of this paper is to contribute to the knowledge of the distribution, population and seasonal dynamics of three species of genus Gammarus (G. roeselii, G. balcanicus and G. fossarum) in the Republic of Kosovo.

\section{MATERIAL AND METHODS}

Quantitative samples of Amphipods were collected with hand nets (mesh size of $0.4 \mathrm{~mm}$ ) on the bottom of five streams and were fixed in $70 \%$ ethanol in the field. Sampling was carried out monthly during 2010 except July. Specimens were sorted in the laboratory using a binocular microscope and were identified to species level using available keys (Karaman \& Pinkster, 1977a, b; Karaman, 1993). Females were distinguished from males by the characters given in KARAMAN \& PINKSTER (1977a, b) such as presence of oostegite plates in females and genital papillae in males, as well as body size and setosity of pereiopods. Juveniles were distinguished from adults by size where for all three species specimens $<8 \mathrm{~mm}$ were treated as juveniles and the rest as adults. Specimens are deposited at the Faculty of Mathematics and Natural Sciences, Department of Biology, University of Prishtina, Prishtina, Kosovo.

The following chemical parameters were measured during the investigation period using an $\mathrm{HI}$ 9828 multimeter: oxygen concentration and saturation, water and air temperature. Alkalinity was measured by titration of a $100 \mathrm{ml}$ water sample with HCL $0.1 \mathrm{~N}$ with the use of methyl orange as indicator.

Gammarids were collected at five localities (Tab. 1, Figs 1 and 2), in five different streams, of which four (S2-S5) are in the Adriatic Sea drainage area and one, S1, is in the Black Sea drainage area. All sampling stations were located in the Municipality of Suharekë in southern Kosovo. Station S1 was located in Duhël, a tributary of Sitnicë River. Station S2 was located in southwestern part of Suharekë town in a stream that originates from Breshanc village. Station S3 is located in the southeastern part of Suharekë town in a stream which originates from Sharr Mountains. Station S4 is located in the northeastern part of Suharekë town. The last station, S5, is a thermal spring located in the northwestern part of the Suharekë town. Three of the sampling stations are located in tributaries of the Toplluhë River in the Drini i Bardhë river basin (S2-Semetisht, S3-Leshan and S4-Dragaqinë). S5 - Banjë was located in a spring area of Banjë thermal springs which after few meters discharges into the Mirushë River.

Tab. 1. Locality data for the five sampling stations.

\begin{tabular}{|c|c|c|c|c|}
\hline Code & Sampling stations & Latitude (N) & Longitude (E) & Altitude (m) \\
\hline S1 & Duhël & $42^{\circ} 25^{\prime} 37^{\prime \prime}$ & $20^{\circ} 54^{\prime} 9^{\prime \prime}$ & 806 \\
\hline S2 & Semetisht & $42^{\circ} 24^{\prime} 34^{\prime \prime}$ & $20^{\circ} 47^{\prime} 13^{\prime \prime}$ & 423 \\
\hline S3 & Leshan & $42^{\circ} 19^{\prime} 40^{\prime \prime}$ & $20^{\circ} 48^{\prime} 20^{\prime \prime}$ & 389 \\
\hline S4 & Dragaqinë & $42^{\circ} 22^{\prime} 10^{\prime \prime}$ & $20^{\circ} 52^{\prime} 36^{\prime \prime}$ & 453 \\
\hline S5 & Banjë & $42^{\circ} 27^{\prime} 50^{\prime \prime}$ & $20^{\circ} 46^{\prime} 43^{\prime \prime}$ & 553 \\
\hline
\end{tabular}



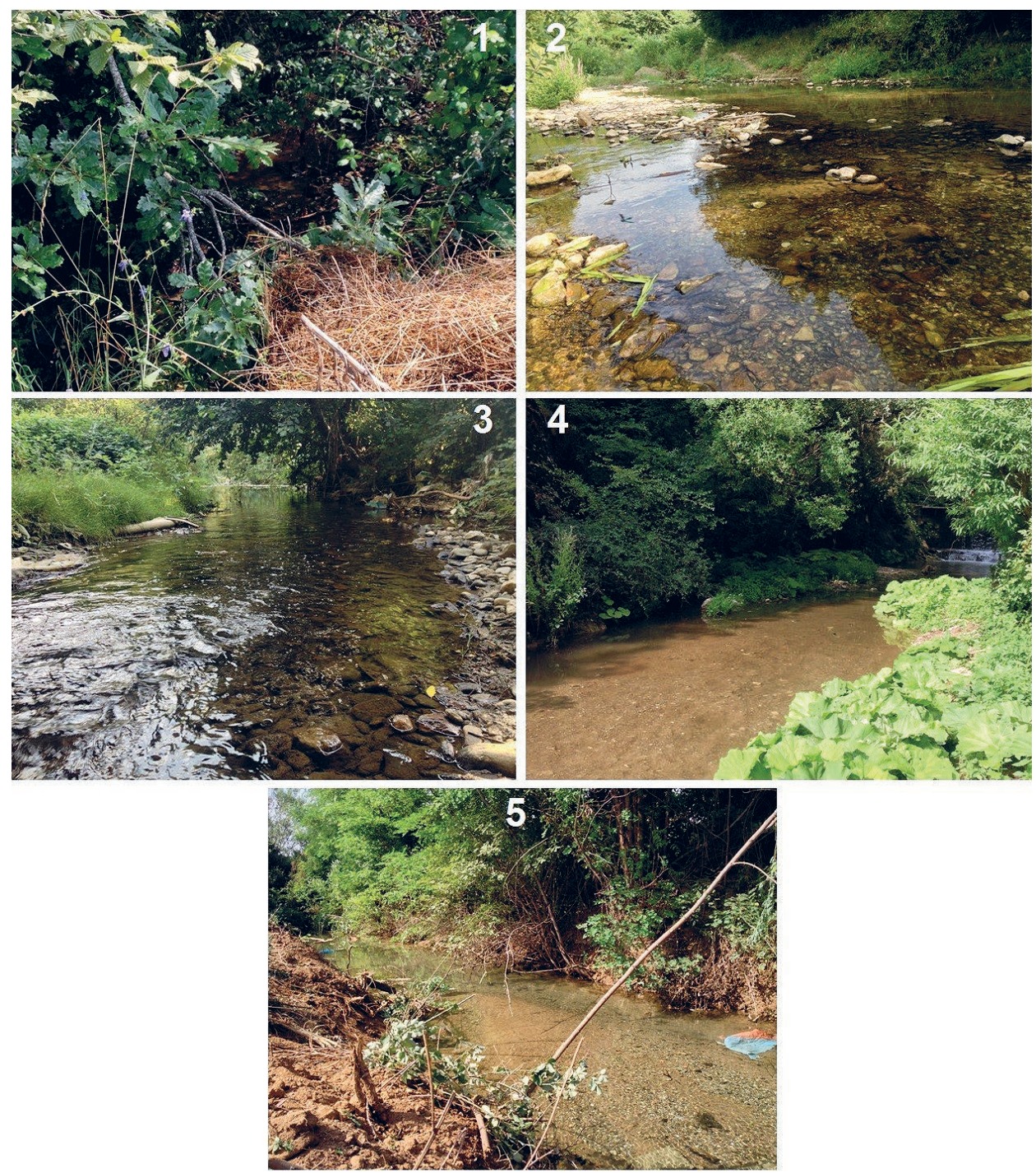

Fig. 1. Sampling stations: 1) S1 Duhël, 2) S2 Semetisht, 3) S3 Leshan, 4) S4 Dragaqinë and 5) S5 Banjë.

\section{RESULTS}

Three species of the genus Gammarus were found: Gammarus balcanicus Schaferna, 1922 at four sites (S1-S4), Gammarus fossarum (Linnaeus, 1758) at three sites (S1, S2 and S4) and Gammarus roeselii Gervais, 1835 at site S5. Species G. balcanicus dominated at four sites (Fig. 3) and at three sampling sites G. balcanicus and G. fossarum were found together in all months with low average relative abundance of last species (0.29-1.7\%). G. roeselii was the sole species found at site S5-Banjë (Fig. 3). Analysis of the population structure of G. roeselii at site S5 revealed presence of egg-bearing (ovigerous) females during the whole year with the minimum percentage of 35.3 in October and maximum of $100 \%$ in December. Sex ratio (males/females) for G. roeselii varied between 0.69:1 during August to 1.47:1 dur- 


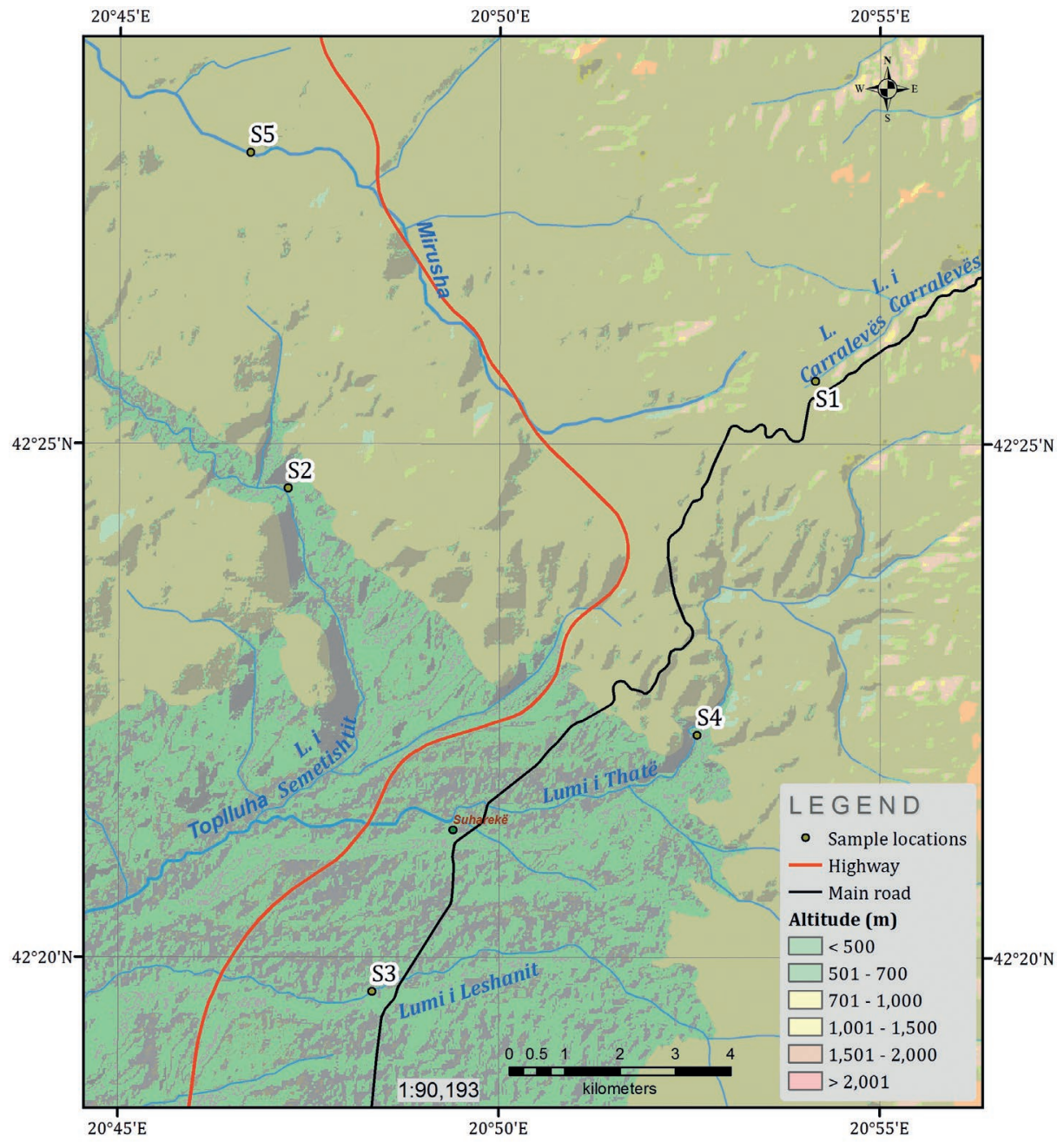

Fig. 2. Sampling stations and the hydrographic network of the research area: S1 Duhël, S2 Semetisht, S3 Leshan, S4 Dragaqinë and S5 Banjë.

ing February (Fig. 4). The highest percentage of juveniles in the population of G. roeselii is registered during November and January, the lowest during August and October. The number of eggs per ovigerous female of G. roeselii varied between 1 and 39, while average number of eggs ranged from 9.7 to 20.3 (Tab. 3).

Average water temperatures varied between $10.8{ }^{\circ} \mathrm{C}$ (S1 Duhël) and $23{ }^{\circ} \mathrm{C}$ (S5 Banjë). The lowest water temperature range was recorded at S5 Banjë and the highest at S4 Dragaqinë (Tab. 2). The highest average value for saturation with $\mathrm{O}_{2}$ was registered in S5 Banjë (95\%) and the lowest average value in S4 Dragaqinë (74.9\%). Average values of dissolved oxygen in water varied between $7.89 \mathrm{mg} / \mathrm{l}$ (S4 Dragaqinë) and $9.74 \mathrm{mg} / 1$ (S3 Leshan). Average alkalinity ranges between 5.0 (S4 Dragaqinë) and 8.5 (S5 Banjë). 


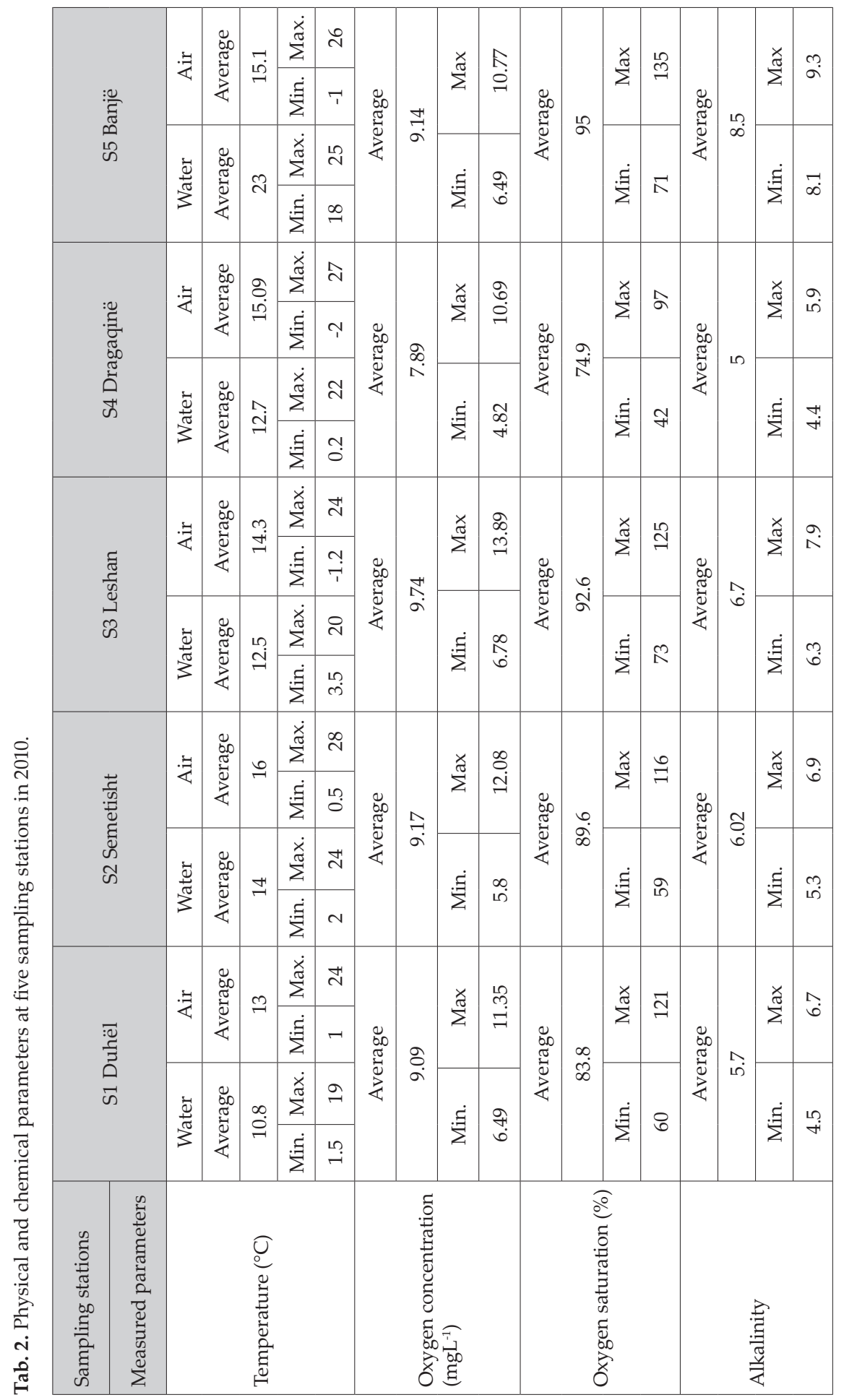




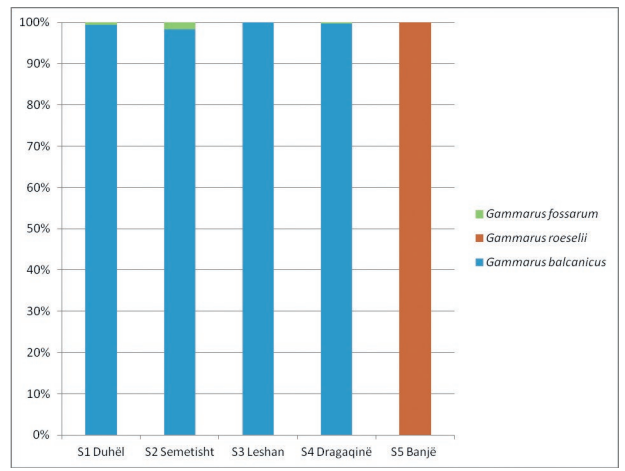

Fig. 3. Relative abundance of three species based on composite samples (all months summed) at all five sampling stations.

a)

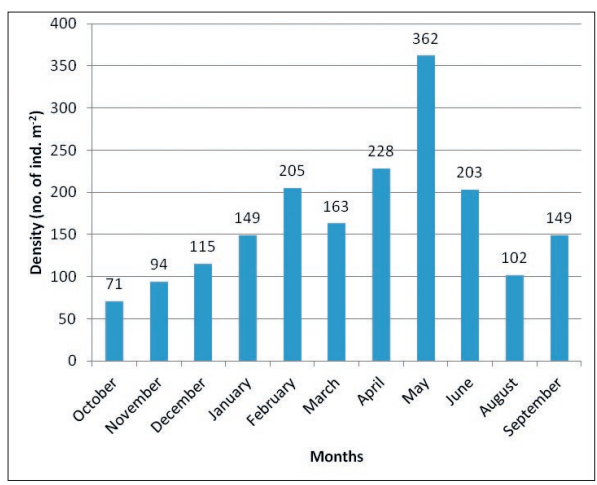

b)

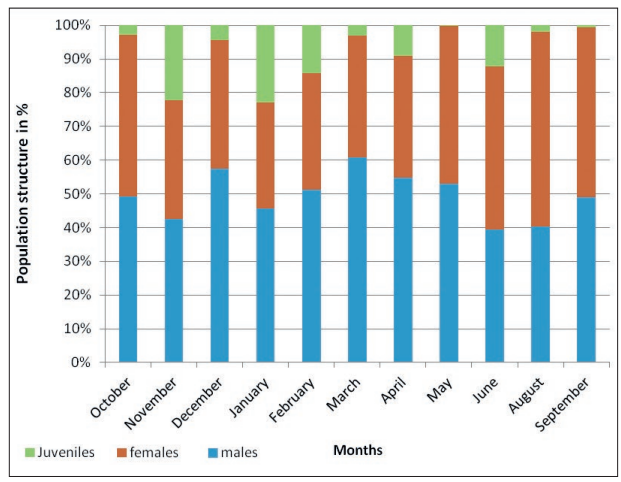

Fig. 4. a) Population density of Gammarus roeselii at site S5 Banjë in 2010; b) population structure of G. roeselii at the same site.

\section{DISCUSSION}

Two species from the family Gammaridae were reported from Kosovo (SHUKRIU, 1976; IвRAHIMI et al., 2008; Žrvić et al., 2012): Gammarus balcanicus and G. fossarum. In this study Gammarus roeselii was found for the first time in the Republic of Kosovo at one sampling station (S5-Banjë), which offers optimal conditions for the development of this species. Gammarus roeselii is a species of Balkan origin which is distributed in Asia Minor and across the European continent (KARAMAN \& PINKsTER, 1977b, Ruffo et al., 1988; ŽGANEC, 2009; GrABowsKi et al., 2017). In this regard Neogene palaeogeography provides a context for understanding the origin and distribution of cryptic diversity of amphipods in the Balkan Peninsula (GRAвоwsкi et al., 2017). The preferred habitat for G. roeselii are streams with moderate water current and abundance of plants; it can even survive in low oxygen concentrations and high temperatures (Pockl et al., 2003; Karaman, 1993).

In this study Gammarus roeselii was previously found at a site located several hundred meters downstream of the Banjë thermal spring where the average annual temperature was $23^{\circ} \mathrm{C}$ (range: $18-25^{\circ} \mathrm{C}$ ). During our investigation we found that optimal temperature conditions for G. roeselii are warm streams while G. fossarum is optimally adapted for summer cool streams (PöckL et al., 2003); G. balcanicus finds optimal conditions in summer cold streams (GrabowsKi \& Mamos, 2011). Similar studies have shown that Gammarus roeselii is more successful in maintaining viable and highly productive populations in waters originating from thermal springs (PöcKL et al., 2003) 
Tab. 3. Percentage contribution of ovigerous females within the total number of females and average number of eggs per female in Gammarus roeselii at S5 Banjë incluiding minimum and maximum values.

\begin{tabular}{|l|c|c|}
\hline \multicolumn{1}{|c|}{ Months } & $\begin{array}{c}\text { Percentage of ovigerous females } \\
\text { within total number of females }\end{array}$ & Eggs \\
\hline October & $\%$ & Average (max-min) \\
\hline November & 35,3 & $11.2(30-5)$ \\
\hline December & 97,0 & $20.3(37-6)$ \\
\hline January & 100,0 & $15.9(31-5)$ \\
\hline February & 95,7 & $15.3(31-4)$ \\
\hline March & 95,8 & $16.9(36-3)$ \\
\hline April & 91,5 & $15.1(36-3)$ \\
\hline May & 93,9 & $15.4(33-3)$ \\
\hline June & 98,8 & $16.8(39-1)$ \\
\hline August & 96,9 & $12.7(24-2)$ \\
\hline September & 76,3 & $9.7(17-3)$ \\
\hline
\end{tabular}

During this investigation we have found a continuous reproduction cycle of G. roeselii throughout the year. Previous studies of G. fossarum and G. roeselii had shown that higher temperatures are generally associated with shorter life spans, faster brood development times, a tendency to produce more broods, and greater reproductive potential capacity in terms of succeeding generations (PöcKL et al., 2003). The lowest number of ovigerous females for G. roeselii was recorded during October. Similar studies reveal a reduced reproduction during autumn (PöckL et al., 2003). In this study, the presence of ovigerous females has been recorded throughout the year in the other two species as well. The population structure analysis of Gammarus roeselii reveals that throughout the whole research period males are dominant in terms of number of individuals with the exception of June, August and September. The dominance of males as compared to female specimens in other species of the genus Gammarus, has been explained by faster growth and earlier attainment of maturity (CIUbuc, 1984; HyNEs, 1955; KRANJČEVIĆ, 2009).

Accurate and detailed data on the diversity, distribution and ecology of species of the genus Gammarus are still lacking for several Balkan countries. Kosovo is one of the least explored countries of Europe in this regard and thus further investigations are needed in order to understand distribution patterns, ecological preferences and anthropogenic impact on the species of this genus. Currently most of the investigations in freshwater ecosystems in Kosovo are limited to water quality assessments (IвRAнimi \& Gashi, 2008; Ibrahimi et al., 2008) with some taxonomic data on EPT (Ephemeroptera, Plecoptera, Trichptera) insect orders (e.g. Gashi et al., 2015a, 2015b; IвRAнiмi et al., 2014, 2015a, 2015b, 2016) but other groups of macroinvertebrates have been only fragmentarily investigated. This investigation contributes to the inventory of freshwater biodiversity of Kosovo.

\section{ACKNOWLEDGEMENT}

We would like to thank Professor Krešimir Žganec for verifying identity of specimens of Gammarus balcanicus, G. fossarum and G. roeselii. We also want to thank him and Professor Michal Grabowski for comments that significantly improved this manuscript. 


\section{REFERENCES}

Altermatt, F., Alther, R., Fišer, C. , Jokela, J., Konec, M., Kury, D., Mächler, El, Stucki, P. \& Westram, A. M., 2014: Diversity and Distribution of Freshwater Amphipod Species in Switzerland (Crustacea: Amphipoda). PlosOne 9 (10), e110328.

Ciubuc, C., 1984: Sex ratio and reproduction cycle of Gammarus balcanicus crustacea amphipoda. Analele Universitatii Bucuresti Biologie 33, 74-82

Davolos, D., Chimenti, C., Ronci, L., Setini, A., Iannilli Vl, Pietrangeli B. \& De Matthaeis E., 2015 : An integrated study on Gammarus elvirae (Crustacea, Amphipoda): perspectives for toxicology of arsenic-contaminated freshwater. Environmental Science and Pollution Research 22 (20), 15563. doi:10.1007/s11356-015-4727-9

Gashi, A., Ibrahimi, H., Grapci-Kotori, L., Sejdiu N. \& Bislimi, K., 2015a: New records of Drusus siveci Malicky, 1981 (Trichoptera, Limnephilidae, Drusinae) from the Balkan Peninsula, with ecological notes. Acta Zoologica Bulgarica 67 (2), 259-264.

Gashi, A., Shabani, E., Grapci-Kotori, L., Bislimi, K., Maxhuni, Q. \& Ibrahimi, H., 2015b: Contribution to the knowledge of fish fauna of Kosovo with a special note on some invasive species. Turkish Journal of Zoology 40 (1), 64-72.

Grabowski, M. \& Mamos, T., 2011: Contact zones, range boundaries, and vertical distribution of three epigean gammarids (Amphipoda) in the Sudeten and Carpathian mountains (Poland). Crustaceana, 84, 153-168.

Grabowski, M. \& Pešić V. 2007: New data on the distribution and checklist of freshwater and brackishwater Gammaridae, Pontogammaridae and Behningiellidae (Amphipoda) in Bulgaria. Lauterbornia 59, 53-62.

Grabowski, M., Mamos, T., Bącela-Spychalska, K., Rewicz, T. \& Wattier, A.R., 2017: Neogene paleogeography provides context for understanding the origin and spatial distribution of cryptic diversity in a widespread Balkan freshwater amphipod. PeerJ 5:e3016

Hynes, H.B.N., 1955: The reproductive cycle of some British freshwater Gammaridae. Journal of Animal Ecology 24, 352-387.

Ibrahimi, H. \& Gashi A., 2008: State of knowledge of investigations on Trichoptera larvae in Kosova. Ferrantia 55, 70-73.

Ibrahimi, H., Dauti, E., Gashi, A. \& Grapci-Kotori, L., 2007: The impact of sewage effluents in water quality and benthic macroinvertebrate diversity of the Prishtina river (Kosova). Entomologica Romanica 12, 227-231.

Ibrahimi, H., Dauti, E., Gashi, A., Trožić -Borovac, S., Skrijelj, R. \& Grapci-Kotori, L., 2008: The impact of sewage effluents in water quality and benthic macroinvertebrate diversity of the Prishtina river (Kosova). Entomologica Romanica 12, 227-231.

Ibrahimi, H., Gashi, A., Bilalli, A., Musliu, M., Grapci Kotori, L. \& Etemi-Zhushi F., 2014: Three new country records from the genus Limnephilus Leach, 1815 (Trichoptera: Limnephilidae) from the Republic of Kosovo. Biodiversity Data Journal 2, e4140. doi: 10.3897/BDJ.2.e4140

Ibrahimi, H., Gashi, A., Grapci-Kotori, L., Bilalli, A., Musliu, M. \& Etemi-Zhushi, F., 2015b: First record of Mesophylax aspersus (Rambur, 1842) from the Republic of Kosovo (Trichoptera Limnephilidae). Biodiversity Journal 6 (1), 3-6.

Ibrahimi, H., Kučinić, M., Vitecek, S., Graf, W., Previšić, A., Bálint, M., Keresztes, L. \& Pauls, S.U., 2015a: New records for the Kosovo caddisfly fauna with description of a new species, Drusus dardanicus sp. nov. (Trichoptera: Limnephilidae). Zootaxa 4032, 551-568. doi: 10.11646/ zootaxa.4032.5.5

Ibrahimi, H., Previšić, A., Vitecek, S., Graf, W., Kučinić, M., Bálint, M., Keresztes, L. \& Pauls, S.U., 2016: Drusus sharrensis sp.n. (Trichoptera, Limnerphilidae) a new species from Sharr National Park in Kosovo with molecular and ecological notes. ZooKeys 559, 107-124. doi: 10.3897/zookeys.559.6350

Karaman, G., 1972: XXXVIII Contribution to the knowledge of the Amphipoda. On the Genus Typhlogammarus (Schaferna) (Fam. Gammaridae) from Yuguslavia. Fragmenta Balcanica Musei Macedonici Scientarum Naturalium 9(3/203), 21-34.

Karaman, G., 1993: Fauna d'Italia: Crustacea - Amphipoda (d'acqua dolce). Edizioni Calderine Bologna, 337 pp.

Karaman, G.S., 1973: New Species of Family Gammaridae From Yugoslavia, Niphargus-deelemaniae n-sp and Typhlogammarus-Algor, n-sp. 48. Contribution to the knowledge of Amphipoda. Archiv Fur Hydrobiologie 72(4), 490-500.

Karaman, G.S., 1974: Catalogus faunae Jugoslaviae: Crustacea Amphipoda. Ljubljana, SAZU, 1-41. 
Karaman, G.S. \& Pinkster, S., 1977a: Freshwater Gammarus species from Europe, North Africa and adjacent regions of Asia (Crustacea, Amphipoda). Part I. Gammarus pulex-group and related species. Bijdragen tot de Dierkunde 47(1), 1-97.

Karaman, G.S. \& Pinkster, S., 1977b: Freshwater Gammarus species from Europe, North Africa and adjacent regions of Asia (Crustacea-Amphipoda). Part II. Gammarus roeseli-group and related species. Bijdragen tot de Dierkunde 47, 165-196.

Karaman, S., 1934: VI Beitrag zur Kenntnis jugoslawischer Susswasseramphipoden. Zoologischer Anzeiger, Leipzig, 107(11/12), 325-333.

Kranjčević, D., 2009: Population structure and dynamics of Gammarus balcanicus (Crustacea, Amphipoda) along the Cetina River. Diploma thesis, Faculty of Science, Department of Biology.

Özbeк, M., Yurga, L. \& KülköLÜoĜLu, O., 2013: Gammarus baysali sp. nov., a new freshwater amphipod species from Turkey (Amphipoda: Gammaridae). Turkish Journal of Zoology 37, 163-171.

PöскL, M, Wевв B.W. \& Sutclife, D.W., 2003: Life history and reproductive capacity of Gammarus fossarum and G. roeseli (Crustacea: Amphipoda) under naturally fluctuating water temperatures: a simulation study. Freshwater Biology 48, 53-66.

Ruffo, S., Turin, P. \& Zanetti, M., 1988: Contributo alla conoscenza della distribuzione degli Anfipodi nel Veneto orientale. Rivista di Idrobiologia 27, 431-448.

SHukriu, A., 1976: Distribucija i dinamika populacija rakušaca (Amphipoda) u slivu Belog Drima. Master Thesis, University of Zagreb.

VäInölä, R, Witt, J., Grabowski, M., Bradbury, J. \& JAZDZewski, K., 2008: Global diversity of amphipods (Amphipoda; Crustacea) in freshwater. Hydrobiologia 595, 241-255.

ŽGANEC, K., 2009: Raspostranjenost i ekologija nadzemnih rakušaca (Amphipoda, Gammaroidea) slatkih i bočatih voda Hrvatske. Doktorska disertacija, Prirodoslovno-matematički fakultet Zagreb, 214 pp.

Žganec, K., Gottstein, S., Grabowski, M. \& Platvoet, D., 2010: Distribution of the endemic amphipod species Echinogammarus thoni (Schäferna, 1922) in watercourses of the Balkan Peninsula. Lauterbornia 69, 41-50.

Žıvić, I. \& MARкović, Z., 2007: Distribution of the species Gammarus balcanicus and Gammarus fossarum on the territory of Serbia (Central part of the Balkan peninsula). Crustaceana 1, (40-136).

Žıvić, N., VuKanić, V., Babović-JaKšić, T. \& Miljanović, B., 2012: Distribution of macrozoobenthos in the tributaries of river Ibar in the northern part of Kosovo. Natura Montenegrina 7 (2), 401-411.

\title{
SUMMARY
}

\section{First record of Gammarus roeselii Gervais, 1835 (Amphipoda: Gammaridae) from Kosovo with ecological notes}

\author{
R. Kuçi, H. Ibrahimi \& A. Gashi
}

The genus Gammarus with more than 200 species is distributed in the Holarctic and Palearctic regions. In the Balkan Peninsula the knowledge about this genus is moderate but there are areas where there is still a lack of data on the taxonomy, biogeography and ecological features of this order. Kosovo is one of the least explored countries in Southeastern Europe with respect to species of the Gammaridae family. During a one year period in five sampling stations in Suharekë Municipality in Kosovo three species of the genus Gammarus were found: Gammarus balcanicus, Gammarus fossarum and Gammarus roeselii. Gammarus roeselii is reported for the first time from the Republic of Kosovo and has been found in one locality only. This locality originates from a thermal water spring where the average yearly temperature is above $19 \mathrm{C}^{\circ}$. Similar studies have shown that Gammarus roeselii is more successful in maintaining viable and highly productive populations in waters originating from thermal springs, while G. balcanicus and G. fossarum are well adapted to cool waters. The population structure analysis of Gammarus roeselii reveals that during most of the research period males were dominant, probably because of their faster growth and earlier attainment of maturity. 